\author{
Marquette University \\ e-Publications@Marquette
}

College of Communication Faculty Research and Publications

$5-2019$

\title{
"Dear Editor: Can You Tell Me What Happened to My Favorite NBC Program, Dimension X?"
}

Amanda R. Keeler

Marquette University, amanda.keeler@marquette.edu

Follow this and additional works at: https://epublications.marquette.edu/comm_fac

Part of the Communication Commons

\section{Recommended Citation}

Keeler, Amanda R., "'Dear Editor: Can You Tell Me What Happened to My Favorite NBC Program, Dimension X?"' (2019). College of Communication Faculty Research and Publications. 525.

https://epublications.marquette.edu/comm_fac/525 
Marquette University

e-Publications@Marquette

\section{Communication Faculty Research and Publications/College of Communications}

This paper is NOT THE PUBLISHED VERSION; but the author's final, peer-reviewed manuscript. The published version may be accessed by following the link in the citation below.

Journal of Radio \& Audio Media, Vol. 26, No. 1 (2019): 50-62. DOI. This article is (C) [Taylor \& Francis(Routledge)] and permission has been granted for this version to appear in $\underline{\text { e- }}$

Publications@Marquette. [Taylor \& Francis(Routledge] does not grant permission for this article to be further copied/distributed or hosted elsewhere without the express permission from [Taylor \& Francis(Routledge].

\section{"Dear Editor: Can You Tell Me What Happened to My Favorite NBC Program, Dimension X?"}

Amanda Keeler

College of Communication, Marquette University, Milwaukee, Wisconsin

Over the course of its seventeen-month run in 1950 and 1951, the science fiction anthology radio program Dimension $X$ served as a showcase for many new and established science fiction writers. Dimension $X$ was among several adult science fiction and fantasy shows that debuted on radio in the late 1940s and early 1950s, alongside CBS's Escape and Mutual's 2000 Plus. While many listeners celebrated these programs, NBC received letters detailing concerns over the subject matter of three episodes. In addition to providing insight into the reception of Dimension $X$, the responses from NBC personnel are equally informative. This back-and-forth communication provides a window into the network's efforts to mitigate and prevent listener issues, as well as the internal divisions regarding appropriate subject matter for radio programs in the early 1950 s. 
The question posed in the title of this article comes from radio listener R. H. C., from Indianapolis, Indiana, who wrote to the Radio Television Mirror column "Information Booth" inquiring about the future of Dimension $X$. The column provided this answer: "The last broadcast of Dimension $X$ was heard on January 29,1951 . Although it is off the air now, there is a possibility that it may be brought back in the future. As yet no definite plans have been made" (August 1951, p. 21). Several months later in early June 1951 Dimension X begin airing new episodes on NBC radio, but the program soon ended again on September 29, 1951. After the program's final broadcast, another listener of the show, New York City resident Millicent DePalma, wrote a short letter to NBC asking the network to "put Dimension X back on the air. As you have not done so yet, thought I write and tell you how much I enjoyed it and I hope you will put it back on soon" (DePalma letter, [ $\underline{6}]$ ). Dimension X's temporary and then permanent absence from radio was acutely felt by its regular listeners. What was so special about this program that its demise garnered such strong reactions from its fans?

Over the course of its seventeen-month run, this science fiction anthology radio program served as a showcase for new and established science fiction writers, including adaptations of stories by Ray Bradbury, Isaac Asimov, and Kurt Vonnegut. Dimension X touted in its opening credits that it would provide listeners with "adventures in time and space, told in future tense."[ 1] Several American radio program guides regard Dimension $X$ as a "high-quality" program (Reinehr \& Swartz, [27], p. 81), and an "excellent adult science-fiction drama series" that "set a high standard that few other programs of its type achieved" (Sies, [28], p. 192). Herb Gilb, reviewing the program for Variety after its premiere episode, wrote that the "performances were good, music properly eerie and in general Dimension $X$ appears assured of wide listenership from those interested in probing the unknown" (Gilb, [ 8 ], p. 34). For NBC, the program was well received and inexpensive to produce. As Tim DeForest ([ $\underline{5}])$ notes, "using staff already under contract to the ne+twork," Dimension X "managed to eek out weekly episodes for about one-sixth the amount of money that the average half-hour series would spend" (p.

186). Dimension X's first producer, Van Woodward, told James Widner and Meade Frierson III ([33]) that the program had a "very limited budget" of approximately $\$ 2,000$ a week, making it far less costly than the $\$ 5,000-\$ 8,000$ per episode cost of the average radio program of this era (p. 29). Both statements are supported in the industry magazine discussions of Dimension X. A Broadcasting Telecasting article from August 1951 describes NBC's "gross costs per week" for Dimension X as \$2,941 (NBC Chime Sale, [24], p. 40).[ 2]

While the program frequently appears on lists of well-regarded dramatic radio programs, the scholarly attention paid to the show has been limited to short comments about the show's genre and its subject material. J. Fred MacDonald ([18]) describes Dimension X as "serious science fiction based on stories by leading writers in the field" (p. 85). Gerald Nachman ([23]) writes that Dimension X was "the best known-or, at least, the most significant-outer-space show ... considered by sci-fi experts the first science-fiction show for adults" (p. 189). Science fiction scholar J. P. Telotte ([31]) praises the program as "especially noteworthy" (p. 171). Several reasons might account for this curious scholarly gap. The most frequent basis for the omission of decades old radio and television programs is a lack of access to the show itself, often because programs were performed live and not recorded. Jason Loviglio ([17]) addresses this in his article about Judy and Jane, whereby his study of this radio drama was primarily through "an archive of scripts and practically no recordings" (p. 307).

However, a lack of extant recordings should not have hampered the study of Dimension X; most of its episodes are easily accessible on the Internet Archive, Old Time Radio, and other radio history enthusiast websites. I argue that the lack of scholarly work around Dimension $X$ points instead to the timing of its debut. As Neil Verma ([32]) notes, "historians of broadcasting tend to pivot swiftly into 
television" after the late 1940s (p. 170). Though radio dramas and anthologies continued into the 1970s in the United States, after 1948 many historical accounts focus primarily on the transition of this type of storytelling from radio to television. Despite historical accounts overlooking "late" radio dramas, in 1950 there were only 3.875 million television households, representing about 9\% of US households (Sterling \& Kittross, [30], p. 657). Yet, in 1950 94.7\% of U.S. households had at least one radio (Sterling \& Kittross, [30], p. 656). Telotte writes that there were several radio anthologies still on the air in 1950, including "long-running series like Suspense (1940-62), Escape (1947-54), and Inner Sanctum (1941-52)" ([31], pp. 170-71). Millions of listeners were still tuning into their favorite programs and new, popular radio programs continued to emerge. While radio programs did lose some listeners who began to watch more television, this shift also presented an opportunity for networks to move away from creating programs that everyone might enjoy into crafting "narrowcast" programming. As Eleanor Patterson ([26]) notes, "niche programming practices" often discussed as part of the growth of cable television in the 1980s and 1990s in the United States, "were, in fact, common practice in radio production from 1950s and onward" (p. 3).

In some ways, Dimension $X$ was a part of a radio renaissance. Dimension $X$ was among several science fiction and fantasy shows that debuted on radio in the early 1950s. Networks recognized the appeal of "specialized shows ... devoted to the fantastic" in the 1940s and 1950s (Telotte, [31], p. 170). As noted in the media industries news magazine Variety, "Everybody wants to do a show with a science-fiction format. Mutual just preemed its 2000, Plus series; NBC is excited over its upcoming Dimension X series. CBS practically did handsprings in some atomic fervor over a Ray Bradbury-scripted show calls Mars in Heaven, and is set to ride with its own weekly series" (Nets nuts, [25], p. 25).

As demonstrated in Millicent DePalma's letter to NBC, and R. H. C's inquiry to Radio Television Mirror, fans of Dimension X implored NBC to continue making episodes after the program was cancelled. However, the radio program also elicited strong reactions from upset and dismayed listeners. Despite the move toward niche audio dramas in the 1950s, not all listeners were ready for radio to shift away from stories that catered to listeners of all ages. DePalma's support letter and the listener complaints regarding episodes of Dimension $X$ have been preserved as part of the NBC papers, housed in the Wisconsin Historical Society archive in Madison, Wisconsin, a priceless resource that has been integral to research on U.S. radio programming, NBC personnel, and the media industries in general. The archive contains three small folders pertaining to Dimension $X$, two of which consist of correspondence and files related to the program's advertising and promotions. The most substantial and illuminating folder for the purposes of this paper contains letters from listeners who wrote to protest certain episodes to which they objected, and the subsequent return correspondence from and between NBC personnel. These letters form an invaluable historical record of the program through its reception among listeners compelled to share their thoughts with NBC executives.

Three episodes provoked several listeners to complain to NBC: Ray Bradbury's "Zero Hour," "No Contact," written by George Lefferts \& Ernest Kinoy, and the last episode of the series, "Nightfall," written by Isaac Asimov. In the next section I will provide synopses of these episodes to contextualize the protest letters listeners sent to NBC. The letters themselves detail the subject matter that three specific listeners objected to or found offensive. While these isolated complaints are illuminating as artefacts documenting the reception of Dimension $X$, the responses from NBC personnel are equally informative. This back-and-forth communication provides a fascinating insight into the network's efforts to mitigate and prevent these sorts of listener issues, as well as the internal divisions regarding appropriate subject matter for radio programs. 


\section{Dimension $X$ and Science Fiction Radio}

The earliest listener letter in the file was written on June 18, 1950 by Ida H. Levine of Teaneck, New Jersey, to station WOR, who forwarded it to NBC. Levine wrote in response to the Saturday June 17, 1950 8:00 p.m. airing of "Zero Hour," written by Ray Bradbury. This short story, originally published in 1947, was adapted by George Lefferts for Dimension X (Widner \& Frierson III, [33], p. 34).[ 3] "Zero Hour" is set on a summer day in 1985, which the narrator describes as typical: the town's men are working in their offices, the children are playing outside, and the mothers are at home preparing food for their families. Mink (Denise Alexander), an eight-year-old girl, is playing a game with the other children called "invasion." Mink tells her mother Mary (Rita Lynn) that the children are getting instructions from Drill, who is "planning the invasion." Mary, and Mink's father Henry (Roger De Koven), are not too alarmed at her imagination, even after Mary's sister Helen tells her that the neighborhood children in her far away city are also playing the same game. At the "zero hour," 5:00 p.m., Drill, an alien being from another dimension, materializes on Earth and orders the children to kill their parents. Mary and Henry flee to their attic to hide, but Mink and her friends find them there. Mink says, "peek-a-boo" and the episode ends. Though ambiguous, it is implied that Drill and the children are about to kill the parents.

In response to the episode, Levine writes, "After listening to your program on June 17, 1950 I was horrified by its implications. At a time when the children are subjected to many undesirable influences, it is tragic to plant the seeds of destruction in young minds and promote attitudes hostile and murderous toward their parents. Although the story is weird in its conception, it is fraught with terrifying implications. I suggest more careful supervision and selecting in the programs produced" (Levine letter to Mutual, [16]). Several days after receiving Levine's complaint letter, Stockton Helffrich, NBC's Continuity Acceptance Manager, replied and thanked her for her letter. He writes,

The program essentially is directed to adults particularly since the fantasy material is sophisticated in tone. We are not, however, unmindful of the fact that children do sometimes listen to evening program material, and I will ask our program builders handling Dimension $X$ to take into account the kind of constructive criticism you have taken the trouble to write. (Helffrich letter to Levine, [10])

This polite response from Helffrich does not overtly apologize or agree with Levine's assessment of the episode. Instead, it suggests that the listener, rather than the network, has an obligation to consider that not all radio programs are suitable for younger audiences. This notion of different audiences for programs at certain times of the day marked a shift away from years of radio programming that sought to attract the largest audience possible. However, as noted earlier, while radio networks were experimenting with creating niche programs, it appears that at least some listeners did not respond to these programming shifts as quickly (or as quietly) as anticipated. Levine's letter demonstrates the tension between programs attempting to create new listener experiences and audiences expecting "post-network" radio to maintain the status quo.

On the same day that Helffrich replied to Levine's letter, he also wrote an internal memo to Dimension $X$ 's first producer, Van Woodward. Here, Helffrich acts on his promise to speak to "our program builders" and goes into more detail about "Zero Hour" with Woodward.[ 4] Helffrich notes,

Frankly I think her criticism is not totally off.... I think it is adult in appeal, but with the show on at 8 o'clock children do listen and could take some encouragement from the theme to 'get back' at adult authority. The script had not been brought to my attention before broadcast and I am asking the 
readers to check more closely with you on any of the science fiction material with integrates too much horror into otherwise acceptable fantasy. (Helffrich memo to Woodward, [13])

The differences between the publicly disseminated message to Levine and the internal message to Woodward are striking, particularly in the division Helffrich makes between "acceptable fantasy" and "horror," which he seems to feel "Zero Hour" transgressed. Even in this moment of emerging niche radio when programs like Dimension $X$ were specifically marked as "adult" programming, the protest in Levine's letter alludes to lingering fears that certain types of subject matter could encourage young people to commit hostile or dangerous acts.

Helffrich did not always agree with listeners nor his colleagues at NBC. In the case of the next complaint letter, Helffrich takes a different stance, both with the original letter writer and the internal discussions in response to the concerns raised by one listener. This set of correspondence begins with a letter, dated November 1, 1950, from Mrs. Dale Melton of Yuma, Arizona to Sid Strotz, NBC executive vice president for the Pacific Coast.[ 5] Melton writes that her letter is intended to "register a strong protest in regards to a program broadcast over N.B.C. last night," referring to the Dimension X episode "No Contact," which originally aired on Saturday April 29, 1950 but was recreated for a second broadcast on Sunday October 29, 1950. Written by George Lefferts and Ernest Kinoy, "No Contact" tells the story of a crew of men on the rocket Starcloud as they leave Earth in 1987 and attempt to break through the "galactic barrier" to reach the remote planet Volta. The rocket's commander, Captain Thorsen (Luis Van Rooten), and its medical doctor, Dr. Smithson, discuss what they call the "space blues" as they travel towards Volta, theorizing that the blue tint that appears on some of the men's bodies might be caused by the rocket's speed of travel and the crew's work-related stress. As Starcloud successfully breaches the galactic barrier a mutiny descends upon the ship. Captain Thorsen finds a transmitting device in Lieutenant Collier's (Donald Buka) quarters and destroys it. Collier confesses that he is really an agent of the Voltan government, and that others like him have been on Earth since 1945. Thorsen is able to radio back to mission control to warn them about an attack and rebellion from within, a "fifth column" plot underway on Earth. The radio operator on Earth, Charlie (Cameron Prud'homme), lies to his superior officer, Coronel Harrison, telling him that there was "no contact" with the Starcloud after it passed through the galactic barrier. The episode ends with Harrison saying, "you'd better go out and get yourself some coffee. Charlie, you look a little blue around the gills," a hint to the audience that Charlie is another Voltan insurgent hiding in plain sight on Earth.In Melton's complaint letter to NBC she describes her reaction to "No Contact." Melton writes,

In my opinion it was fifth column propaganda in the vilest of nature. I'm sure that the high standards of N.B.C. have been violated in this case and it was due to an over sight that such a program was broadcast. As the mother of teenage youngsters who have listened to the program before, I would appreciate a brief comment from you in regards to your opinion on this particular broadcast. (Melton letter to Strotz, [20]).

As the previous letter from Levine regarding "Zero Hour" noted, Melton takes issue with the idea that impressionable children might be listening to this episode. In Helffrich's reply letter, he tells Levine that Dimension $X$ is "directed to adults," a notion reiterated in many contemporary descriptions of the show (Sies, [28], p. 192). Helffrich goes on to tell Melton, "Frankly I am at a loss in my effort to understand where you see in the broadcast titled 'No Contact' as done October 29 'Fifth Column propaganda in vilest of nature'" (Helffrich letter to Melton, [11]). After recapping the episode's story to clarify the subject matter of "No Contact," Helffrich notes that the episode: 
is sheer fantasy and in context of the series very definitely is not intended to be confused by listeners with very real headlines on international affairs currently perplexing us all. Your letter is much appreciated. We always like to hear from our audience, but your letter is the only such reaction received and we do earnestly request your re-evaluation of the two broadcasts of this story. (Helffrich letter to Melton, [11])

Helffrich's response is unambiguous. He largely refutes Melton's interpretation of the episode, again referring to the "fantasy" genre to indicate the storytelling leeway permissible within this type of program. While Helffrich acknowledges that the world of 1950 has "perplexing" political anxieties, he makes it clear that the episode was not meant to be read as a directive to listeners.

Helffrich's response to Melton did not end the discussion over this episode, however. Melton's letter prompted another internal discussion that employed Melton's letter as ammunition against Helffrich and his work. Melton's original letter was sent to Sid Strotz, who forwarded the letter to Don Honrath, head of the Continuity Acceptance department for NBC's western division in Hollywood. Honrath in turn wrote to Helffrich the following note:

Attached is a letter of complaint on the Dimension X Show which originates in your territory... For your information I have heard several other remarks regarding this show along the same lines particularly the one on "Genetics". I understand it got a very unfavorable reaction from the Catholics. You might browse around and see what you come up with on this show. (Honrath memo to Helffrich, [15])

Honrath's disapproval of Dimension $X$ appears not to be limited to merely one episode. What is particularly striking in Honrath's memo, however, is not the disapproval noted in the above exchange but the final two sentences of this letter, in which Honrath essentially calls Helffrich a communist for reasons not clear in this exchange. Honrath writes, "I looked for your name in Red Channels but it will probably turn up in a supplementary edition. If mine ever appears in it this is one goddam capitalist who'll sue the shirts off them bastards. Regards" (Honrath memo to Helffrich, [15]). By mentioning Red Channels, Honrath appears to use Melton's letter as an indication that Dimension X, as well as Stockton Helffrich, seem somehow to be playing around with communist propaganda that potentially disturbed and offended more than just the original letter writer. As Robert DeSpain ([ ] ] notes, Red Channels "was published by the American Business Consultants" and "former FBI agents" who has previously used the newsletter Counterattack "to openly combat domestic communism by publishing any evidence of communist activities or sympathies" (p. 408). Although it is impossible to conclude if Honrath was attempting to be humorous in his allegation that Helffrich might be a communist, this type of comment would have been taken seriously in 1950. While the information contained in publications such as Red Channels was highly suspect, accusations of associations with communists or sympathies toward communism nonetheless had the power to end the careers of people working in the media industries during the Cold War years (Meyers, [21]). Helffrich's response to Don Honrath refutes this unfounded claim, and takes umbrage with the lack of specific, concrete details in Honrath's memo. In Helffrich twopage response, he writes,

Miss Barnard here who handles audience mail received none pro or con either on 'Hello Tomorrow' or 'No Contact'... Who therefore are the people making these remarks to you?... We are in the public relations business up to our ears and I am flatly unable in meetings with the Management here to give them a clear picture of your problems there on the basis of a statement telling me that you 'uncovered several little items (not to be set down here)...' Don, very soberly, why couldn't you 'set down here' anything you have uncovered? (Helffrich memo to Honrath, [12]) 
Unlike the internal correspondence between Helffrich and Woodward regarding "Zero Hour," here Helffrich has the opposite reaction. Rather than Helffrich asking the show's producer for more careful consideration of the stories told on Dimension X, Helffrich not only disagrees with Melton's original letter complaining about "No Contact," but also disputes the veracity of Honrath's suggestion that he has heard numerous complaints regarding Dimension $X$. Helffrich ends his memo to Honrath by declaring, "as a matter of fact in a series like 'Dimension $X$ ' it is almost going beyond phantasy into the realm of 'the story with a message' and the message is highly ethical" (Helffrich memo to Honrath, [15]). In the context of this exchange of words with Honrath over "No Contact," Helffrich is quick to defend Dimension X. Yet, in the case of "Zero Hour" noted above, and regarding his impression of the episode "Nightfall," written by Isaac Asimov and adapted for radio by Ernest Kinoy, his memos suggest that he felt that the show was guilty of transgressing acceptable storytelling boundaries on occasion.

On September 29, 1951 at 8:00 p.m. the science fiction radio anthology Dimension X aired what would prove to be the last episode of the series. "Nightfall" features characters who are presumably human, living on an Earth-like planet that has six suns. It is daylight on this planet for all 23.8 hours of the day. Theremon (Lyle Sudrow), a reporter, goes to an astronomy observatory to interview Dr. Aton (Cameron Prud'homme) after Aton and his colleagues declare that the world "is coming to an end." A religious group, the "cult of revelations," has also declared the world will end, per their "doctrine of revelations." The planet is on the eve of an eclipse that happens every 2049 years. The eclipse, prophesied to be the "end of civilization," will bring a darkness during which mysterious stars appear and madness descends. Dr. Sheerin (John McGovern) tells Theremon that "man cannot exist without light" and proves this by taking him to Latimer, who "lost his mind" after spending fifteen minutes in the dark. The scientists and the religious group are fighting a battle between science and faith. Theremon and Sheerin try to understand how people have bought into the "doctrine of revelations." On the night of the eclipse, one of the cultists tries to stop the astronomers from taking pictures of the stars. The cultists form a mob and attempt to storm the observatory. The stars appear at the moment of the eclipse, the scientists appear to go mad, and cities all over the planet burn.

Several days after "Nightfall" aired, Pastor Harold Snider, from the Calvary Bible Church, Sunbury Road, Lewistown, PA sent a letter to the president of NBC, to discuss the episode. He writes,

I have listened to this program with varying degrees of fascination heretofore, but last Saturday night it reached new heights of ridicule. It was a very plain burlesque of the Christian faith, using such terms as 'Revelations' 'saints' 'sin' 'heaven' 'Damnation' and 'glory' in such fashion as to cause the listeners to revolt. In this program, your writers have trespassed into a sacred precinct which will not be soon forgiven.... I do not know what type of censorship you employ but as a Christian, and one who believes the message of the Christian gospel is more urgently needed in this day than all else, I wish to register my own protest. Dimension $X$ should make an apology to its listeners for dragging sacred terminology into the dust.... Please accept this as constructive criticism. (Snider letter to NBC, [29])[ 6 ]

Snider takes umbrage with the use of terms that are closely associated with the bible, though "Nightfall" uses the plural "Revelations" rather than the correct spelling "Revelation." The addition of the "s" was clearly not enough to persuade this listener that the story was science fiction, as he felt that it had too many close associations with "the Christian faith."

On October 22, 1951 Anita Barnard (writing as A. L. Barnard) of NBC's Department of Information, responded to Pastor Snider's letter.[ ㄱ] She notes, 
The comments, particularly those concerning the terminology used in a "Dimension X" broadcast has been brought to the attention of our Continuity Acceptance Department, in order that they may take note of the possible implications in uses of words which are generally attached to religious beliefs. We do not believe, however, that the writers of this particular episode intended any burlesque of scriptural terms.... We are grateful for your consideration in letting us know your reactions. NBC is glad to have had the opportunity to express its views on the matter (Barnard letter to Snider, [1])

As was the case with Helffrich's letter to Levine in response to her complaint about "Zero Hour," Barnard suggests that, while they appreciated Pastor Snider's letter and his criticism, NBC had not intended to "burlesque" his faith traditions. However, Snider's letter again prompted some internal division at NBC over the contents of Asimov's story. In a memo sent to File, cc'ing Dimension X's second producer William Welch, Stockton Helffrich questions how this episode ended up on the air in the first place. Helffrich writes,

This one having been answered there is not much point going further but on a look at the script I do feel editing was in order to avoid any offense to any religious sects giving fundamental support to the Book of Revelations.... This two-sided aspect seems reasonable, but in the context of the script seems to me to be on pretty touchy ground these days of increasing religiosity ... should such a script come in to us again I think we would do very well to avoid identifying such fanaticism with a specific section of the bible. It is one thing to discuss this kind of business in a forum program but something else again to make a mockery of fundamentalists. I don't think this particular offering had any place in Dimension X as a series... (Helffrich memo to File, [14])

As with the episode "Zero Hour," Helffrich agrees with Snider's protests regarding "Nightfall." However, by the time that Snider's letter was received by NBC, the network had already cancelled Dimension X. At the end of "Nightfall" the announcer and host Norman Rose tells the audience, "with this program Dimension X concludes the present series. We hope to return to the air in the near future. Watch your local newspaper or listen to your local station for the resumption of the series." Nonetheless, Barnard answered Snider's letter and addressed his concerns.

\section{Conclusion}

From these three isolated protest letters, it is impossible to make larger assumptions about how other listeners experienced and interpreted Dimension $X$. Nor is it possible to conclude from the memos between Helffrich, Honrath, and Barnard how much, if at all, these letters influenced the stories presented on the program. These three case studies do suggest that Helffrich was flexible enough to accommodate listener complaints while also defending the show when he saw fit. His responses, as well as Barnard's letter to Snider, indicate that the network was careful not to offend listeners purposefully. However, it did not seem to occur to Dimension $X^{\prime}$ 's producers that some subject matter might prove offensive to certain audiences or open to negative interpretations.

A document in the Dimension $X$ files indicates that at least one episode required revision per the Continuity Acceptance Department. The August 9, 1951 episode of the program, titled "The Veldt," was listed as "too brutal" in a memo between Judy Chenkin and Dimension X producer Van Woodward. The memo notes,

In the futuristic bit of sadism - two little monsters solve the how-to-get-along-with-one's-parents problem by feeding them to some hungry lions.... This seemed a far too believable, drastic and hostile way to deal with two pleasant adults. We requested that the audience be warned in an introduction of 
the character of the piece so that parents with impressionable children can ban them from the radio room if they wish. (Continuity Changes memo, [ 4])

Although this memo suggested placing a warning at the beginning of "The Veldt," no such warning appears in the extant recording found on internetarchive.org. Indeed, this Continuity Changes memo hints at the disconnect between how Dimension $X$ is discussed today, as an "adult" science fiction program, and the clear sense that NBC was nonetheless acknowledging that children listened to the program, suggesting that the transition from mass audience to niche programming was not a smooth or easy endeavor.

Each of the three episodes of Dimension $X$ discussed in this article is a fascinating product of how science fiction writers at the time attempted to imagine and construct their vision of the future. These episodes continue to resonate with audiences because they depict believable settings and characters, amid unsettling events that are not beyond the realm of possibility, imbued with social and political issues with which we continue to grapple. The mention of a "fifth column" attack from within, in both "No Contact" and "Zero Hour," remarks on some post-World War II fears over the power of enemy forces and the possibilities of outsiders or "others" infiltrating unbeknownst to people just going about their regular, daily lives - fears that have not disappeared even after the dissolution of the Cold War. However, it is unclear how much these stories or this program might have been responding to the Cold War.

Other elements of these stories remain timeless, such as the natural inclination of children to have vivid imaginations - and their parents' decision to ignore what appear to only be creative flourishes until it is too late-as suggested in "Zero Hour." Even though it is set 35 years in the future, Bradbury's story largely reproduces 1950 s hierarchies of power, in which parents are dismissive of their children's thoughts and ideas, and where Henry refuses to listen to or trust his wife Mary even when she repeatedly tells him about what is really going on with the children and Drill. From the perspective of writing radio histories in 2018, it is curious that science fiction writers such as Bradbury and Asimov could imagine futures with invading aliens, inter-dimensional travel, and rocket ships to far away planets, but failed to imagine a woman working outside of the home. Furthermore, neither writer thought to include any female characters at all in both "No Contact" and "Nightfall."

As M. Keith Booker ([ 2] ]) notes, Dimension X, like many science fiction programs, "often reflected contemporary anxieties about the dangers of technology" (pp. 4-5). Science fiction has also long been a disguise to "[force] its audience to consider the existential, social and political problems of the day" (Mortenson, [22], p. 57). Interestingly, though technology is often a centerpiece of science fiction storytelling, it is not the main focus of the three episodes that prompted complaint letters. These episodes are much more concerned with fear of other people, human or alien, and their power to bring about uprisings from within one's own house, rocket ship, or planet, only a few years after the unsettling global events of World War II.

\section{References}

Barnard, A. L. (1951, October 22). Letter from Anita Barnard to Pastor Harold Snider. NBC papers. Box 151, Folder 20. Madison, WI : Wisconsin Historical Society.

Booker, M. K. (2004). Science fiction television. Westport, CT : Praeger.

C., R. H. (1951, August). Letter from R. H. C. to "Information Booth." Radio Television Mirror, p. 21. 
Continuity changes memo. (1951, August 1) Continuity changes regarding Dimension X requesting audience warning before broadcast, negotiated with Judy Chenkin and Van Woodward. NBC papers. Box 151, Folder 20. Madison, WI : Wisconsin Historical Society.

DeForest, T. (2008). Radio by the book: Adaptations of literature and fiction on the airwaves. Jefferson, NC: McFarland \& Company, Inc. Publishers.

DePalma, M. (1952, September 1). Letter from Millicent DePalma to NBC. NBC papers. Box 349, Folder 41. Madison, WI : Wisconsin Historical Society.

DeSpain, R. (2011). William L. Shirer and the blacklist: The drive against a liberal radio commentator. Historical Journal of Film, Radio and Television, 31 (3), 399 - 417. doi: 10.1080/01439685.2011.597996

8 Gilb, H. (1950, April 12). Review of Dimension X. Variety, 178, 34

9 Goldin, J. D. (2018). Dimension X episode index. Retrieved from http://radiogoldindex.com/cgilocal/p2.cgi?Program Name=Dimension $+X$

Helffrich, S. (1950, June 22). Letter from Stockton Helffrich to Ida H. Levine. NBC papers. Box 151, Folder 20. Madison, WI : Wisconsin Historical Society.

Helffrich, S. (1950, November 13). Letter from Stockton Helffrich to Mrs. Dale Melton. NBC papers. Box 151, Folder 20. Madison, WI : Wisconsin Historical Society.

Helffrich, S. (1950, November 13). Memo from Stockton Helffrich to Don Honrath. NBC papers. Box 151, Folder 20. Madison, WI : Wisconsin Historical Society.

Helffrich, S. (1950, June 22). Memo from Stockton Helffrich to Van Woodward. NBC papers. Box 151, Folder 20. Madison, WI : Wisconsin Historical Society.

Helffrich, S. (1951, November 2). Memo from Stockton Helffrich to File. NBC papers. Box 151, Folder 20. Madison, WI : Wisconsin Historical Society.

Honrath, D. (1950, November 3). Memo from Don Honrath to Stockton Helffrich. NBC papers. Box 151, Folder 20. Madison, WI : Wisconsin Historical Society.

Levine, I. H. (1950, June 18). Letter from Ida H. Levine to WOR. NBC papers. Box 151, Folder 20. Madison, WI : Wisconsin Historical Society.

Loviglio, J. (2016). Reading Judy and Jane in the archive. Journal of Radio \& Audio Media, 23 (2), 306 - 322. doi: 10.1080/19376529.2016.1224424

MacDonald, J. F. (1979). Don't touch that dial: radio programming in american life from 1920 to 1960. Chicago : Nelson Hall Inc., Publishers.

Martin, C. (2019). In their own little corner: The gendered sidelining of NBC's Information Department. Journal of Radio \& Audio Media, 26 (1). forthcoming.

Melton, D. (1950, November 1). Letter from Mrs. Dale Melton to Sid Strotz. NBC papers. Box 151, Folder 20. Madison, WI : Wisconsin Historical Society.

Meyers, C. B. (2016). Advertising, the red scare, and the blacklist: BBDO, US Steel, and Theatre Guild on the Air, 1945-1952. Cinema Journal, 55 (4), 55 - 83. Retrieved from http://0muse.jhu.edu.libus.csd.mu.edu/article/624931

Mortenson, E. (2014). A journey into the shadows: The Twilight Zone 's visual critique of the Cold War. Science Fiction Film and Television, 7 (1), 55 - 76. doi: 10.3828/sfftv.2014.3 
Nachman, G. (1998). Raised on radio. New York, NY : Pantheon Books.

NBC Chime Sale Plan. (1951, August 6). NBC Chime Sales. Broadcasting Telecasting, 41 (27), 40.

Nets Nuts Over Science-Fiction; 'Mars' Panics 'Em. (1950, March 22). Variety, 178, 25.

Patterson, E. (2016). Reconfiguring radio drama after television: The historical significance of Theatre 5, Earplay and CBS Radio Mystery Theater as post-network radio drama. Historical Journal of Film, Radio and Television, 36 (4), 649 - 667. doi: 10.1080/01439685.2016.1157287

Reinehr, R. C., \& Swartz, J. D. (2008). Historical dictionary of old-time radio. Lanham, MD : Scarecrow Press.

Sies, L. F. (2008). Encyclopedia of American radio, 1920-1960 (2nd ed.). Jefferson, NC : McFarland \& Company, Inc.

Snider, H. (1951, October 4). Letter from Pastor Harold Snider to the president of NBC. NBC papers. Box 151, Folder 20. Madison, WI : Wisconsin Historical Society.

Sterling, C. H., \& Kittross, J. M. (1990). Stay tuned: A concise history of American broadcasting (2nd ed.). Belmont, CA : Wadsworth Publishing Company.

Telotte, J. P. (2014). Radio and television. In R. Latham (Ed.), The Oxford handbook of science fiction (pp. $168-$ 183). New York, NY: Oxford University Press.

Verma, N. (2012). Theater of the mind: Imagination, aesthetics, and American radio drama. Chicago, IL : University of Chicago Press.

Widner, J. F., \& Frierson III, M. (1996). Science fiction on radio: A revised look at 1950-1975. Birmingham: A.F.A.B. 